Teaching French with the Direct Method between 1880 and 1920 in the United States of America: A comparative Analysis of key Direct Methods Textbooks

\title{
Ariane Ruyffelaert
}

\section{(2) OpenEdition}

\section{Journals}

Electronic version

URL: https://journals.openedition.org/dhfles/7631

DOI: $10.4000 /$ dhfles.7631

ISSN: 2221-4038

\section{Publisher}

Société Internationale pour l'Histoire du Français Langue Étrangère ou Seconde

Printed version

Date of publication: 1 December 2020

Number of pages: 317-332

ISSN: 0992-7654

\section{Electronic reference}

Ariane Ruyffelaert, "Teaching French with the Direct Method between 1880 and 1920 in the United States of America: A comparative Analysis of key Direct Methods Textbooks", Documents pour /'histoire du français langue étrangère ou seconde [Online], 64-65 | 2020, Online since 02 February 2021, connection on 25 March 2023. URL: http://journals.openedition.org/dhfles/7631 ; DOI: https://doi.org/ $10.4000 /$ dhfles.7631

This text was automatically generated on 25 March 2023.

All rights reserved 


\title{
Teaching French with the Direct Method between 1880 and 1920 in the United States of America: A comparative Analysis of key Direct Methods Textbooks
}

\author{
Ariane Ruyffelaert
}

\section{Introduction}

1 In the 1880s, a movement to reform modern language teaching was launched mainly in Germany and Scandinavia. This reform movement, called the "direct" method, was developed in response to the Grammar Translation Method. It spread throughout the rest of Europe and as well as to the United States of America (USA), which is the subject of this study.

2 The history of the direct method in foreign language teaching has already been studied a great deal, with the six volumes of Foundations of Foreign Language Teaching (Howatt \& Smith 2000), and the five volumes of Modern Language Teaching: The Reform Movement (Howatt \& Smith 2002). Other studies focused more on a broad description of the teaching of modern languages such as French, German, Spanish and Italian in the USA (Handschin 1913); or on a British and European perspective (Howatt \& Smith 2014). As Howatt \& Smith (2014) indicated, historical research is also relatively well developed concerning the international teaching of French (see Besse 2014). However, the direct method in French foreign language teaching has been studied less from an international perspective, outside Europe, for instance in the USA and additionally at a specific period (1880-1920) ${ }^{1}$, which is precisely the main purpose of this study.

With regards to more recent studies, Finotti conducted a detailed analysis, describing main concerns of the Lambert Sauveur's direct method textbooks and pedagogy 
(Finotti 2010; Finotti 2013). Finotti also described Sauveur's method and how it related to the one of Berlitz (Besse 2010: 234). However, an analysis of the key features of the work made by other recognized authors of the direct method teaching French in the USA deserves to be explored through a comparative perspective. In this context, this study describes, on the one hand, the direct method according to Lambert Sauveur (1826-1907), one of the precursors of this method in the USA in the $19^{\text {th }}$ century. On the other hand, the current study provides a comparative analysis of the early key authors of direct methods textbooks for teaching French in the USA between 1880 and 1920, such as Maximilian Berlitz, known for the Berlitz Schools, James Worman, Joseph Gaillard, Charles Hall Grandgent and John Ernst Matzke (Table).

Table: List of some direct method textbooks used in the USA between 1880-1920

\begin{tabular}{|c|c|c|}
\hline Author & Textbook & Year \\
\hline Lambert Sauveur & $\begin{array}{l}\text { Causeries avec mes élèves } \\
\text { Petites causeries } \\
\text { Causeries avec les enfants }\end{array}$ & $\begin{array}{l}1874 \\
1875 \\
1875\end{array}$ \\
\hline Maximilian Berlitz & $\begin{array}{l}\text { Premier livre pour adultes } \\
\text { Deuxième livre pour adultes } \\
\text { Édition illustrée pour les enfants } \\
\text { Grammaire pratique en } 4 \text { volumes } \\
\text { Français commercial }\end{array}$ & $\begin{array}{l}1902 \\
1902 \\
1897 \\
1899 \\
1917\end{array}$ \\
\hline James Worman & $\begin{array}{l}\text { L'Écho de Paris. The French Echo: Dialogues to Teach French } \\
\text { Conversations. }\end{array}$ & 1870 \\
\hline Joseph Gaillard & The Modern French Method & 1884 \\
\hline $\begin{array}{l}\text { Charles } \quad \text { Hall } \\
\text { Grandgent }\end{array}$ & A short French Grammar & 1894 \\
\hline John Ernst Matzke & A Primer of French Conversation & 1897 \\
\hline
\end{tabular}

\section{Background about the reception of the reform movement in the USA}

Before comparing the main authors of the direct method in the USA and their textbooks between 1880 and 1920, background information is provided of earlier publications about the beginning and the reception of this new teaching method during that specific period of time.

5 In 1963, George Watts published an interesting report on the history of French teaching in the USA. He reported on the growing interest in modern language study and focused specifically on French as a foreign language. This report gave a broad overview of the historical development of teaching French and the educational policy that differed by school type (public elementary, secondary, and religious schools, colleges, universities, 
trade schools, language institutes, and first-year programs abroad). In addition, he described the types of texts, techniques, and teaching equipment that were used in the USA since the fourteenth and fifteenth centuries (Watts 1963).

6 According to Purin (1916), in the USA, the "natural method" was brought into prominence from the 1870 s by men like Gottlieb Heness, Sauveur \& Berlitz. Indeed, Heness is considered as the rediscoverer or reinterpreter of the "natural method" in 1866 (Watts 1963). A few years later, he was joined by Lambert Sauveur, who was convinced that the spoken use of the foreign language arouses more interest and that the learners should learn a foreign language as children learn their mother tongues (Watts 1963: 114).

7 Concerning the reception and the success of the direct method, the Report of the Committee of Twelve (1899) said of the "natural" method that it "is a principle, rather than a plan; and its products depend, to a greater extent than those of any other school, on the personality of the instructor" (Report 1899: 1397). However, the Report did acknowledge that the method awakens enthusiasm among its students, that it stimulates and holds the attention, and that the results of the movement "have been mainly good" (Watts 1963: 114). Purin (1916) also affirmed that this method was quite successful with younger children, but the method failed when tried out in public schools, even in the hands of the ablest teachers. For this reason, it gradually fell into disrepute and all efforts to perpetuate it were strongly opposed by American educators (Purin 1916: 46). According to Schweitzer \& Simonnot (1917), the failure might also be because there was no general agreement among modern foreign language teachers regarding the aims or the methodology used.

With regards to Anglo-American universities, they gave great importance to the study of modern language and new trends were well received. As Schweitzer \& Simonnot (1917) described:

[...] what is most detrimental to the extension of the direct method, which is above all an oral method, are the pronunciation defects of its teachers. Too far from Europe to perfect their studies there, they have, to strengthen their conversational skills, and only foreign teachers are in charge of specialized pronunciation courses at the universities (Schweitzer \& Simonnot 1917: 26).

In contrast, Schweitzer \& Simonnot (1917) said that foreign teachers, hardly operated except in private schools (e.g. Berlitz schools). Finally, at that time, public opinion, reflecting the needs of society, demanded that languages were taught in a more practical, more utilitarian way (Schweitzer \& Simonnot 1917).

\section{Lambert Sauveur, one of the precursors of the direct method in the USA}

10 Lambert Sauveur, a linguist of French origin and teacher of French as a foreign language, is considered as one of the precursors of the direct method in the USA in the $19^{\text {th }}$ century.

11 In the 1860s-1870s, Sauveur, like Maximilian Berlitz himself, migrated to the USA and devoted his career mainly to teaching the French language. Sauveur's Natural Method, as he called it, was based entirely on conversation (Howatt 1984: 281). Indeed, Finotti (2010) said he was one of the first to adopt and therefore introduce the direct method 
in the USA. Finotti (2010) claimed that Sauveur is, together with Berlitz, one of the initiators of this new method, opposing the Grammar Translation Method commonly used at that time. Sauveur even created private schools where only his teaching method was used. These schools were located in New York, Philadelphia, and Boston and he also organized summer courses. Sauveur's aim was that students learn to express themselves directly in a foreign language, without the intermediary of a mental translation from one's mother tongue.

\section{Sauveur's books and publications}

As mentioned above, this study focuses first on Sauveur, his books and publications, the specific characteristics, the interrogative approach, the techniques, and the resources used in his foreign language teaching. Sauveur's method was based on active oral interaction in the target language. Thus, the courses were given in the form of a dialogue between teacher and student. In addition, repetition played an important role and it is only when students had considerable knowledge of the spoken language that they moved on to the study of written language and inductive grammar instruction.

Sauveur published several books that broke with tradition, describing the teaching method; and he also published grammars, sometimes accompanied by practical exercises. He also described this new and original approach as a methodology without the use of a grammar book or dictionary during the first month of study, as Howatt \& Smith (2000) describe in Part I: Introduction to the Teaching of Living Languages without grammar or dictionary (1874), About Lambert Sauveur and Maximilian Berlitz in Volume 5 of Foundations of Foreign Language Teaching: Nineteenth-century Innovators.

In the following dialogue (Sauveur 1874a), a student asks why grammar is not explicitly taught, why he does not study grammar. As mentioned above, it is only when students have considerable knowledge of the spoken language that they move on to the study of grammar.

- Ouvrirons-nous la grammaire, monsieur? Pourquoi non?

L. Sauveur: Quand le moment sera venu, nous l'étudierons profondément.

- La grammaire est-elle bête?

L. Sauveur: Oh! que non. Elle nous inspire la plus grande admiration, quand nous la comprenons.

- Faut-il commencer ou finir par la grammaire?

L. Sauveur: Vous voyez bien que nous ne commençons pas par la grammaire, et cependant vous me comprenez.

(Sauveur 1874a, chap. 10, "Les oreilles - Les écouteurs")

In this dialogue, Sauveur answered that in fact, one does not start with grammar and that even if one does not study grammar, the students can understand the teacher. According to Sauveur, grammar should not be the starting point, but only the culmination and the crowning achievement of modern language studies. Thus, it should be taught in advanced courses and learned inductively. However, Sauveur did insert a very small number of grammatical observations into his speeches.

Regarding his publications, the three volumes of Causeries (Causeries avec mes élèves (1874a); Petites causeries (1875c); Causeries avec les enfants (1875a)) represent the heart of Sauveur's method. They were textbooks for a younger audience. Among these works, Petites Causeries stands out because it is one of the three books that constitute the nucleus of Sauveur's method, which was republished by Wentworth Press in 2018. 


\section{Sauveur's methodology}

As mentioned before, Sauveur used an interactive methodology with emphasis on oral language. Indeed, Sauveur used questions (using gestures, drawings, and objects) to introduce and stimulate the use of the foreign language. It was a fast alternation of questions and answers in the target language, as shown in the following example of a dialogue (Sauveur 1874a):

L. Sauveur: À quelle heure déjeunez-vous, madame?

- Je déjeune à sept heures et demie.

L. Sauveur: Et vous, mademoiselle?

- Je déjeune à sept heures.

L. Sauveur: Vous déjeunez plus tôt que madame. Et vous, mon ami?

- Je déjeune à neuf heures et demie.

L. Sauveur: C'est bien tard. Je suis sûr que vous vous levez tard aussi.

- Je me lève à neuf heures.

Sauveur 1874a, chap. 7, "Les repas"

This dialogue is an example in which the conjugation of a verb and a tense were taught: the verb déjeuner "to have breakfast", a regular verb ending on -er, and the pronominal verb se lever "to get up".

19 The advantages of the interrogative approach are that the teacher is continuously seeking the student's attention and can avoid the use of the mother tongue. The importance given to the oral dimension of the target language is stressed: "The interrogative method, by its very nature, eliminates the translation that is no longer needed. Students, like their teachers, speak French from the first hour and do not pronounce a word of English." (Sauveur 1874a: 6).

From what the author himself said, and from the number of letters and articles published in American newspapers celebrating Sauveur's work, suggesting that his method received much support (Finotti 2010). The great success of his books is also confirmed by the fact that they are all published by the three leading publishers in this field. Moreover, thanks to his courses and his works, Sauveur enjoyed certain renown in the country that welcomed him, even an "immense popularity" according to Geddes (1930: 252), an author who attended Sauveur's courses in his youth, and who considered him as "the principal interpreter [...] of the natural method" (Finotti 2010: 11).

\section{Other advocates of the direct method of teaching French in the USA}

This study seeks to give an overview in a comparative perspective of other advocates of the direct method, teaching French in the USA between 1880 and 1920, such as Maximilian Berlitz, known for the Berlitz Schools, James Worman, Joseph Gaillard, Charles Hall Grandgent and John Ernst Matzke.

First, Maximilian Berlitz, of German origin and a linguist like Sauveur, was a professor of German and French who migrated to Providence, Rhode Island (USA) in 1870. According to Howatt \& Smith (2014), his initial ideas came from Gottlieb Heness, a German emigrant to the USA, an educationalist, and his French colleague Lambert 
Sauveur, who developed what they called "The Natural Method". This method was dependent on the teacher's ability to teach the meaning of new words by object lessons, pictures, mime, context, and so on (Howatt \& Smith 2014: 83).

Berlitz, like Sauveur, prioritized oral skills and is considered a prolific textbook author (Finotti 2010). He made original and interesting contributions, especially in the organization of teaching materials. For his modern language courses, he designed textbooks for adults and children. Refining the techniques of Sauveur, Berlitz used, for example, murals or notebooks with pictures in his textbooks. However, he published not only textbooks for adults (Premier livre pour adultes; Deuxième livre pour adultes) and children (Édition illustrée pour les enfants), but also books entirely devoted to grammar or pronunciation and spelling (Grammaire pratique en 4 volumes: I. Les verbes appris par la conversation; II. Nom, pronom, adjectif, article; III. Adverbe, préposition, conjonction et observations générales; IV. Prononciation et orthographe) and other French teaching-related textbooks (e.g. Français commercial).

Due to the success of the method and his work, the first German and French versions were translated into the main European languages and Berlitz was the founder of Berlitz Language Schools in Providence, Rhode Island (1878), Boston, New York, and Washington.

Concerning his methodology, the Berlitz method was a natural way of learning new languages with an intuitive and conversational teaching style. Like Sauveur's method, with the Berlitz method all classroom communication took place in the target language. This conversational approach was based on listening and speaking and the immersive environment encouraged students to quickly develop their competence in oral communication. Even beginners were able to formulate simple sentences from the first class.

Second, James Worman, a Professor of modern languages in Adelphi Academy, and later in Vanderbilt University in Nashville (USA), is considered as advocate of the "natural method" with adaptations (Watts 1963). Even before the successful use of the Sauveur's method, Worman had published a manual of French conversation, called L'Écho de Paris. The French Echo: Dialogues to Teach French Conversation (1870). It was designed to supply students with an extensive vocabulary of words and expressions in common use among the French people and to aid them in obtaining command of the idioms of the language. It was a manual where real-life, everyday vocabulary was of great importance. For instance, the author presented an informal conversation in which he referred to the Jardin des Tuileries, wine, water from a carafe, and the habit of eating bread with cheese or jams. At the end of the manual there is a glossary, listing the vocabulary alphabetically. Unlike other textbooks by other authors, this one translated directly into English, the mother tongue of the learners. In addition, after this vocabulary list, a list of first names, surnames and countries were listed, with their translations or explanations.

27 It seems important to mention that, according to Worman, no grammar, not even the so-called "Conversation Grammars", would enable the learner to master French heard in business, on travel, at a hotel, or in the common conversation of every day. Nevertheless, some years later, Worman published a series of textbooks in which he introduced grammar. Compared to the books of Sauveur, Worman's could be used for self-study. His most important contribution to modern-language teaching was The Worman or Chautauqua series of texts for the study of French, German, and Spanish, in which 
he included the teaching of grammar. His work was intended for beginners wishing to learn the spoken language of France. Each chapter was organized in the same way: a small frame with the grammatical theme of the lesson, then on the next page, a conversation using that particular grammatical aspect. Unlike other authors such as Berlitz, here there were no exercises with blanks that the learner had to fill in. Another aspect that also differed in his publications is that he published teacher's guides for his books.

Finally, the method he used, had the following characteristics:

- To teach modern language without the use or the help of the learner's native language.

- The use of pictorial illustrations of the mentioned objects.

- Grammar was taught to enable the learner to speak accurately because "All other elementary textbooks, after the natural method, ignore the difficulties of grammar, and thus tend to make the learner superficial". This little book aimed to supply a progressive course unfolding the principles of the language.

- The grammatical rules were deduced from examples.

- Everything was taught by contrast and association.

- The lessons were conversations on familiar subjects and topics of an interesting character.

- Already in the first lesson, the learners got to know the variable inflections of nouns, verbs, and so on.

Third, Joseph Gaillard of New York also published a series of French school textbooks in the 1880s, including The Modern French Method (1884). In its preface, Gaillard observed that "The modern method, combing mental drill with the study of French as here developed, is a complete innovation in the art of language teaching" (Gaillard 1884: Preface). The author used a continuous story, but, he first taught pronunciation and the elementary principles of grammar, such as the verbs. In a second phase, he gave a section of this story without the connecting words but he did give the missing function words and prepositions. This material formed then the basis of classroom dialogues and conversation.

Finally, the insistence on the phonetic drill by Viëtor remained as one of the leading characteristics of the reform method, as practiced in Europe. In the USA, there were a few early advocates of this plan but there was usually much less emphasis on phonetic drills (Watts 1963). However, Charles Hall Grandgent and John Ernst Matzke included phonetics in their publications.

31 Grandgent, romance philologist, was a Professor of Romance language at Harvard University (between 1896-1932), formerly Director of modern language instruction in the Boston public schools and, author of A short French Grammar Based on Phonetics (1894) intended for beginners. The purpose of this book was to provide a scientific but intelligible study of French pronunciation through grammar. He attempted to compare systematically French with American English so that beginner students could grasp the characteristics of the new language and understand the structure more thoroughly (Grandgent 1894: Preface). Grandgent recommended his grammar book be used as a reference and with his lessons and exercises book French lessons and exercises during a first year's course in French, for high schools (Grandgent 1894: Appendix I) or colleges (Grandgent 1894: Appendix II). These exercises, illustrating the grammatical points discussed in his grammar book, were based on a French story of Guy de Maupassant, accompanied by an interlinear translation to English (Grandgent 1894: Preface). Finally, 
Grandgent (1894) observed that he consulted the works of Paul Passy among others and that one of his colleagues, Matzke, revised the proofs of his grammar book.

John Ernst Matzke was a Professor of Romanic languages at the Leland Stanford Jr. University (between 1893-1910) and author of A Primer of French Pronunciation (1897). According to Matzke, the only valid methodology with satisfactory results in foreign language learning was the use of phonetics. However, he was not convinced about the books published by Passy and other authors because they were not suitable for younger learners without any knowledge of phonetics (Matzke 1897: Preface). Hence, A Primer of French Pronunciation (1897) attempted to introduce phonetics more gradually, and pronunciation was taught simultaneously with the system of phonetic transcription. Like Grandgent, Matzke also compared French systematically with English. His book was structured as follows: He began with an explanatory table of phonetic symbols and the letters of the French alphabet. Next, he addressed the vowels then dealt with the consonants, exemplifying each particularity with illustrative sentences in French with its phonetic transcription. Finally, auxiliaries and regular conjugations were discussed. Throughout the text, Matzke stressed the difficulties that American English-speaking students could experience, the most common faults to be avoided and described the differences between French and English pronunciation, illustrating with examples. Matzke ended his book with a text of Alphonse Daudet with full phonetic transcription.

\section{Discussion and conclusion}

This study has described the teaching of French as a foreign language using the direct method in the USA between 1880 and 1920 including Lambert Sauveur, whose fundamental principles gives priority to oral language and, emphasized the importance of body language and the use of the target language in the classroom. Indeed, Howatt \& Smith stressed that "the dominant theme of this period was the need to promote the teaching of the spoken language as the main pedagogical priority since, it was argued, speech is the primary foundation of all language activity" (2014: 81).

Comparing the fundamental principles of Lambert Sauveur and those of other advocates of the direct method, we observe that Berlitz, Worman, and Gaillard all emphasized the importance of conversation in the target language in the classroom, without the use of the learner's mother tongue. Another important aspect is the teaching of grammar. While Sauveur was convinced that grammar should not be taught during the first years of study, he published textbooks focused on grammar as did Worman. On the other hand, Berlitz and Gaillard gave more importance to grammar in the teaching of French as a foreign language. Furthermore, it is crucial to note that every author adds different aspects to their teaching. This can be explained by the fact that there was no unified method label for the Reform Movement (Howatt \& Smith 2014: 92). Indeed, different teachers do not blindly follow the methodology of other teachers of their time. For instance, in contrast to Sauveur, Worman had an impact on publishing guides for teachers. Thus, his strategy probably helped other teachers use his textbooks correctly. Moreover, his grammar textbooks also enabled self-study which seems to be something revolutionary at this time. Finally, the works of Grandgent and Matzke seem to belong more to a group of teachers who have given special importance to phonetics, one of the leading characteristics of the reform method, as practiced in Europe (Watts 1963: 116). As Howatt \& Smith (2014) noted, the 
influence of phonetics is obvious, and this particular period represents the beginning of a long history of the connection between foreign language teaching and linguistics.

In conclusion, after more than a century, the direct method, the manuals and didactic resources developed by Lambert Sauveur, Maximilian Berlitz and other advocates of the direct method, remain interesting to this day, for teachers and researchers interested in the history of French foreign language teaching and learning for didactic purposes. In fact, it is interesting to observe how language teaching materials were conceived and organized for the foreign language classroom at that particular time. Finally, this study highlights the importance of critical analyses focused on the evolution of French foreign language teaching over time which are necessary in order to identify an effective teaching methodology or approach, and to carry out a successful teaching and learning experience. However, more studies focusing on the historical evolution of French language learning and teaching and its methodologies used in the USA are still needed.

\section{BIBLIOGRAPHY}

\section{Primary sources}

BERLITZ, Maximilian Delphinius (1897). Méthode Berlitz pour l'enseignement des langues modernes. Édition illustrée pour les enfants.

BERLITZ, Maximilian Delphinius (1899). Grammaire Pratique de la Langue Française, 4 Vols. New York: Berlitz and Co.

BERLITZ, Maximilian Delphinius (1902). Premier livre pour l'enseignement des langues modernes: partie française pour adultes. Nauck \& Company.

BERLITZ, Maximilian Delphinius (1902). Deuxième livre pour l'enseignement des langues modernes: partie française pour adultes. Siegfried Cronbach.

BERLITZ, Maximilian Delphinius (1917). Le français commercial.

GAILLARD, Joseph (1884). The Modern French Method: A Natural, Attractive, and Certain Mode of Acquiring the Art of Thinking, Speaking, and Composing in the French Language: Based Upon the Principle of "association of Ideas". New York: D. Appleton and Company.

GRANDGENT, Charles Hall (1894). A short French Grammar. Boston: D.C. Heath \& Co.

MATZKE, John Ernst (1897). A Primer of French Pronunciation.

SAUVEUR, Lambert (1874a). Causeries avec mes élèves. New York: F.W. Christern, Boston: C.

Schoenhof.

SAUVEUR, Lambert (1874b). Introduction to the Teaching of Living Languages without Grammar or Dictionary. Boston - New York: F. W. Christern.

SAUVEUR, Lambert (1875a). Causeries avec les enfants. New York: Christern.

SAUVEUR, Lambert (1875b). Entretiens sur la grammaire. New York: Christern, Boston: C. Schœnhof. 
SAUVEUR, Lambert (1875c). Petites causeries. Boston: Schœnhof et Mœller, New York: F. W.

Christern.

WORMAN, James (1870). L'Écho de Paris. The French Echo: Dialogues to Teach French Conversation. New York: American Book Company.

\section{Secondary sources}

BESSE, Henri (2010). “Irene Finotti. Lambert Sauveur à l'ombre de Maximilian Berlitz. Les débuts de la méthode directe aux États-Unis". Documents pour l'histoire du français langue étrangère ou seconde, 45, 232-239.

BESSE, Henri (2014). “La Société Internationale pour l'Histoire du Français Langue Étrangère ou Seconde (SIHFLES), ou vingt-cinq ans d'investigations historiographiques sur l'enseignement/ apprentissage du français langue étrangère ou seconde". Language \& History, 57(1), 26-43.

FINOTTI, Irene (2010). Lambert Sauveur à l'ombre de Maximilian Berlitz: Les débuts de la méthode directe aux États-Unis. Bologne: Cooperativa Libraria Universitaria Editrice Bologna.

FINOTTI, Irene (2013). "Le sauveur de la grammaire ou la grammaire de Sauveur? L'enseignement des normes d'après l'initiateur de la méthode directe". Documents pour l'histoire du français langue étrangère ou seconde, 51, 179-193.

GEDDES, James (1930). “Quelques inconvénients des signes et symboles phonétiques”. The French Review, 3, 4, 252-260.

HANDSCHIN, Charles Hart (1913). The Teaching of Modern Languages in the United States. Washington. HOWATT, Anthony P. R. (1984). “Language teaching traditions: 1884 revisited”. ELT Journal, 38(4), 279-282.

HOWATT, Anthony P. R. \& SMITH, Richard (eds.) (2000). Foundations of Foreign Language Teaching: Nineteenth-century Innovators. v. 1. Joseph Jacotot and James Hamilton. v. 2. Claude Marcel (1). v. 3. Claude Marcel (2). v. 4. Thomas Prendergast. v. 5. Lambert Sauveur and Maximilian Berlitz. v. 6. François Gouin. London: Routledge.

HOWATT, Anthony P. R. \& SMITH, Richard C. (eds.) (2002). Modern Language Teaching: The Reform Movement. 5 volumes. London: Routledge.

HOWATT, Anthony P. R. \& SMITH, Richard (2014). “The History of Teaching English as a Foreign Language, from a British and European Perspective”. Language \& History, 57: 1, 75-95.

JESPERSEN, Otto (1904). How to Teach a Foreign Language. London: Swan Sonnenschein. [Translation by S. YhlenOlsen Bertelsen of Sprogundervisning, 1901. Copenhagen: Schuboteske Forlag]. MODERN LANGUAGE ASSOCIATION (1899). Report of the Committee of Twelve of the Modern Language Association of America. Washington, U.S.: Government Printing Office.

PURIN, Charles M. (1916). “The Direct Teaching of Modern Foreign Languages in American High Schools". The Modern Language Journal, 1, 2, 43-51.

SCHWEITZER, Charles \& SIMONNOT, Émile (1917). Méthodologie des langues vivantes. Paris: A. Colin. WATTS, George B. (1963). “The Teaching of French in the United States. A History”. The French Review, 37: 1-165. 


\section{NOTES}

1. Concerning foreign language teaching and methodology, Howatt \& Smith (2014) presented a new division into four periods of activity over the past 250 years. They call this particular period of time (1880-1920) the "Reform Period" during which the core concern was teaching the spoken language. The associated teaching methods are various: Reform Methods (see Jespersen 1904: 23), The Natural Method (Heness, Sauveur), The Berlitz Method and The Direct Method.

\section{ABSTRACTS}

This study aims to compare the key authors of direct methods textbooks for teaching French in the USA between 1880 and 1920. After a short background about the reception of the direct method in French foreign language teaching in the USA, this article describes the method according to Lambert Sauveur (1826-1907), one of the precursors in the USA in the $19^{\text {th }}$ century. In addition, a comparative analysis of other recognized authors of the direct method, teaching French in the USA, such as Berlitz, Worman, Gaillard, Grandgent and Matzke, was performed. In conclusion, on the one hand, this study describes the fundamental principles of Sauveur's direct method (such as the priority given to oral language, the importance of body language, and the use of the target language in the classroom); and on the other hand, it sheds light on the approach in the textbooks of other authors teaching French in the USA between 1880 and 1920.

Cette étude vise à comparer les principaux auteurs de manuels de la méthode directe pour l'enseignement du français aux États-Unis entre 1880 et 1920. Après un bref aperçu de la réception de la méthode directe dans l'enseignement du français langue étrangère aux ÉtatsUnis, cet article décrit la méthode selon Lambert Sauveur (1826-1907), un des précurseurs de cette méthode aux États-Unis au XIX ${ }^{\mathrm{e}}$ siècle. En outre, une analyse comparative d'autres auteurs reconnus de la méthode directe, enseignant le français aux États-Unis, tels que Berlitz, Worman, Gaillard, Grandgent et Matzke a été réalisée. En conclusion, d'une part, cette étude décrit les principes fondamentaux de la méthode directe de Sauveur (tels que la priorité accordée à la langue orale, l'importance du langage corporel et l'utilisation de la langue cible en classe), et d'autre part, elle apporte un éclairage sur l'approche d'autres auteurs de manuels enseignant le français aux États-Unis entre 1880 et 1920.

\section{INDEX}

Mots-clés: méthode directe, Lambert Sauveur, États-Unis, enseignement de langues étrangères, français comme langue étrangère

Keywords: direct method, Lambert Sauveur, United States of America, foreign language teaching, French as a foreign language 


\section{AUTHOR}

\section{ARIANE RUYFFELAERT}

University of Granada

- aruyffelaert@ugr.es 